\title{
Vibrio litoralis sp. nov., isolated from a Yellow Sea tidal flat in Korea
}

Correspondence

Jin-Woo Bae

baejw@kribb.re.kr

\author{
Young-Do Nam, ${ }^{1,2}$ Ho-Won Chang, ${ }^{1}$ Ja Ryeong Park, ${ }_{1}^{1}$ Hyuk-Yong Kwon, ${ }^{1}$ \\ Zhe-Xue Quan, ${ }^{1,3}$ Yong-Ha Park, ${ }^{1,4}$ Byung-Chun Kim ${ }^{4}$ \\ and Jin-Woo Bae ${ }^{1,2,5}$ \\ ${ }^{1}$ Biological Resource Center, KRIBB, 52 Oeundong, Yusong, Daejeon 305-333, Korea \\ ${ }^{2}$ University of Science and Technology, 52, Eoeun-dong, Yuseong-gu, Daejeon 305-333, Korea \\ ${ }^{3}$ Department of Microbiology and Microbial Engineering, School of Life Sciences, Fudan \\ University, Shanghai 200433, People's Republic of China \\ ${ }^{4}$ Department of Applied Microbiology, Yeungnam University, 214-1 Dae-dong Gyeongsan-si, \\ Gyeongsangbuk-do 712-749, Korea \\ ${ }^{5}$ Environmental Biotechnology National Core Research Center, Kyungsang National University, \\ Jinju, Korea
}

\begin{abstract}
Two Gram-negative, facultatively anaerobic bacterial strains, MANO22D ${ }^{\top}$ and MANO22P, were isolated from a tidal flat area of Dae-Chun, Chung-Nam, Korea. The isolates were rod-shaped and were motile by means of one or more polar flagella. They grew at $1-12 \% \mathrm{NaCl}, 4-45^{\circ} \mathrm{C}$ and $\mathrm{pH}$ 4.1-8.8 and were oxidase-positive, arginine dihydrolase-negative and sensitive to the vibriostatic agent $\mathrm{O} / 129$. The isolates required $\mathrm{Na}^{+}$for growth, produced acid, but no gas, from $\mathrm{D}$-glucose under anaerobic conditions and utilized a wide range of compounds as sole carbon and energy sources. A phylogenetic analysis based on 16S rRNA gene sequences revealed that the strains belong to the Gammaproteobacteria and are specifically related to Vibrio species. They were most closely related to Vibrio rumoiensis FERM $\mathrm{P}-14531^{\top}$, with which they were found to share $98.65 \% 16 \mathrm{~S}$ rRNA gene sequence similarity. In the phylogenetic tree, the two novel strains comprised a relatively long subline of descent, sharing a branching point with the outlying species $V$. rumoiensis, and were found to occupy a phylogenetically distant position on the main Vibrio branch. The levels of DNA-DNA hybridization with respect to $V$. rumoiensis FERM P-14531 ${ }^{\top}$, which is their most closely related phylogenetically related Vibrio species, were $7.4 \%$ (MANO22D ${ }^{\top}$ ) and 3.9\% (MANO22P). Thus, the two novel isolates appear to represent a novel species within the genus Vibrio, for which the name Vibrio litoralis sp. nov. is proposed. The type strain is MANO22D $D^{\top}\left(=\operatorname{KCTC} 12520^{\top}=\mathrm{DSM} 17657^{\top}\right)$.
\end{abstract}

The genus Vibrio belongs to the family Vibrionaceae (Baumann \& Schubert, 1984), which includes the genera Photobacterium (Baumann \& Baumann, 1984), Salinivibrio (Mellado et al., 1996) and Grimontia (Thompson et al., 2003) amongst others. Micro-organisms belonging to the genus Vibrio occur frequently in aquatic environments, particularly in marine and estuarine waters, where they are often found associated with various organisms ranging from plankton to fish (Thompson et al., 2004). While some Vibrio species act beneficially in host organisms as probionts (Gomez-Gil et al., 1998, 2000, 2002), others are known to

The GenBank/EMBL/DDBJ accession numbers for the 16S rRNA gene sequences of strains MANO22D ${ }^{\top}$ and MANO22P are D0097523 and DQ097524, respectively. cause disease in fish (Hjeltnes \& Roberts, 1993), crustaceans (Lightner, 1993) and molluscs (Austin, 1988). The number of species assigned to the genus Vibrio increased from 20 in 1981 to 63 in 2004 (Thompson et al., 2004); at the time of writing, this genus includes 76 species with validly published names.

To clarify our understanding of the genus Vibrio, we searched for novel strains of this taxon in getbol, the Korean term for tidal flats. The western and south-western coastlines of the Korean peninsula consist primarily of such tidal flats (Kim et al., 2004). They are unique among other marine sediments as they alternately undergo flooding with seawater and exposure to air (Kim et al., 2005). Two novel strains were isolated from a tidal flat area near DaeChun, Chung-Nam, Korea ( $36^{\circ} 17^{\prime} 45.2^{\prime \prime} \mathrm{N} 126^{\circ} 31^{\prime} 9.5^{\prime \prime} \mathrm{E}$ ) 
by employing the dilution plating technique and culturing the micro-organisms at $25^{\circ} \mathrm{C}$ for 3 days on marine agar 2216 (MA; Difco). These strains were designated as MANO22D ${ }^{\mathrm{T}}$ and MANO22P. Below, we report the phenotypic, genetic and chemotaxonomic analyses that we performed to elucidate the taxonomic position occupied by these strains. These analyses revealed that both strains are very similar; they belong to the family Vibrionaceae and are most closely related to Vibrio rumoiensis.

In our analyses, V. rumoiensis FERM $\mathrm{P}-14531^{\mathrm{T}}$, obtained from Dr I. Yumoto (Yumoto et al., 1999), served as the reference strain. Bacterial cultures of the isolates and the reference strain were stored at $-80{ }^{\circ} \mathrm{C}$ on marine broth $(\mathrm{MB})$ containing $20 \%$ glycerol and were cultured in $\mathrm{MB}$ at $25^{\circ} \mathrm{C}$, with shaking, for morphological and physiological characterization. API 20NE and API ZYM test strips (bioMérieux) and Biolog GN metabolic fingerprinting plates were used to analyse these strains biochemically and physiologically; other biochemical tests were performed using the methods and media described by Gordon et al. (1973). The ability to grow on various carbon sources was tested as described by Gonzalez et al. (1997), and catalase activity was determined by assessing bubble production in a $3 \%(\mathrm{v} / \mathrm{v})$ hydrogen peroxide solution. Oxidase activity was determined by using an oxidase reagent (bioMérieux), while sensitivity to O/129 (150 $\mu \mathrm{g}$ per disc) was determined with Oxoid discs. Growth under anaerobic conditions was determined on MA with anaerobic incubation for 7 days in GasPak jars (BBL) containing an $\mathrm{N}_{2} / \mathrm{CO}_{2} / \mathrm{H}_{2}(80: 10: 10)$ atmosphere. Growth in $\mathrm{MB}$ at various $\mathrm{NaCl}$ concentrations, temperatures and $\mathrm{pHs}$ was measured. The Gram reaction was determined by using a Gram-stain kit (Difco) according to the manufacturer's instructions. Cellular morphology and sporulation were determined by using microscopy (E600; Nikon). The cellular motility of young bacterial cultures in MB was observed in fresh wet mounts by using the hanging drop method. For observation using transmission electron microscopy, cells from exponentially grown cultures were negatively stained with $1 \%(\mathrm{w} / \mathrm{v})$ phosphotungstic acid.
After air drying, the grid was examined using a model $\mathrm{H}$ 7600 transmission electron microscope (Hitachi). The strains were grown on MA for 3 days at $25^{\circ} \mathrm{C}$ to analyse their fatty acid methyl esters, which were extracted and prepared according to standard protocols provided by the MIDI/Hewlett Packard Microbial Identification System (Sasser, 1990). Chromosomal DNA was extracted and purified as described by Sambrook et al. (1989). The 16S rRNA gene was amplified by using a PCR with two universal primers, as described previously (Yoon et al., 1998). Sequencing of the amplified 16S rRNA gene and phylogenetic analysis were performed according to the methods described by Yoon et al. (2003). DNA-DNA hybridization was performed fluorometrically by using the method of Bae et al. (2005) with Cy5-labelled DNA probes and genomespotted microarrays. The $16 \mathrm{~S}$ rRNA gene sequences of the two novel isolates were aligned with 17 reference sequences obtained from the Ribosomal Database Project (Fig. 1) by using the multiple sequence alignment program CLUSTAL_X (version 1.8) (Thompson et al., 1997). The phylogenetic relationships between representatives of the genus Vibrio were determined by using MEGA software (version 2.1). Distance matrices were determined by adopting the assumptions described by Kimura (1980). These matrices were used to elaborate dendrograms by using the neighbour-joining method (Saitou \& Nei, 1987). A bootstrap analysis designed to establish the stability of the phylogenetic trees obtained was performed by obtaining a consensus tree based on 1000 randomly generated datasets.

Strains MANO22D ${ }^{\mathrm{T}}$ and MANO22P were largely identical in their morphological, cultural, physiological and biochemical characteristics. The characteristics of the two isolates are shown in Table 1 and are described in the species description below. They were motile and Gram-negative and their cells were rod-shaped (measuring $0.6-0.8$ by 2.0-3.0 $\mu \mathrm{m}$ on MA). After 3 days growth on MA, their colonies were pale yellow in colour, $1.5-2.0 \mathrm{~mm}$ in diameter, smooth, and circular to slightly irregular in shape. They grew at temperatures ranging from 4 to $45^{\circ} \mathrm{C}$

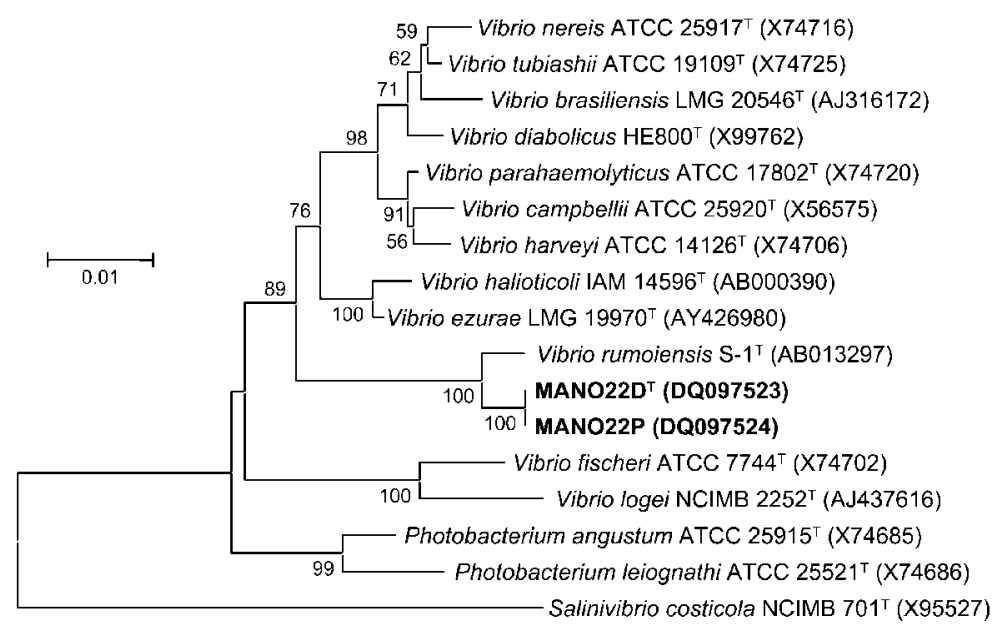

Fig. 1. Consensus neighbour-joining phylogenetic tree, based on 16S rRNA gene sequences, that shows how strain MANO22D ${ }^{\top}$ relates to type strains of selected Vibrio species and representatives of related genera. Bootstrap analysis was based on 1000 repetitions; only values higher than $50 \%$ are shown. The GenBank accession number for each species is shown in parentheses. Bar, 0.01 substitutions per nucleotide position. 
Table 1. Taxonomic characteristics of the novel isolates MANO22D ${ }^{\top}$, MANO22P and their closest phylogenetic relative, V. rumoiensis FERM $\mathrm{P}-14531^{\top}$

Strains: 1, V. rumoiensis FERM P-14531 $1^{\mathrm{T}}$; 2, MANO22D ${ }^{\mathrm{T}}$; 3, MANO22P. + , Positive; -, negative; ND, not determined. All strains showed pale-yellow pigmentation, grew at 4 and $35^{\circ} \mathrm{C}$, produced gas from glucose and showed sensitivity to $\mathrm{O} / 129(150 \mu \mathrm{g})$.

\begin{tabular}{|c|c|c|c|}
\hline Characteristic & 1 & 2 & 3 \\
\hline \multicolumn{4}{|l|}{ Production of: } \\
\hline Valine arylamidase & - & + & + \\
\hline$N$-Acetyl- $\beta$-glucosaminidase & - & + & + \\
\hline \multicolumn{4}{|l|}{ Utilization of: } \\
\hline Glycogen & + & - & - \\
\hline Tween 80 & - & + & + \\
\hline$N$-Acetyl-D-galactosamine & - & + & + \\
\hline Galactose & - & + & + \\
\hline D-Mannitol & - & + & + \\
\hline Sucrose & + & - & - \\
\hline Monomethyl succinate & + & - & - \\
\hline D-Gluconic acid & - & + & + \\
\hline Succinic acid & + & - & - \\
\hline Bromosuccinic acid & + & - & - \\
\hline L-Alanine & - & + & - \\
\hline L-Alanyl glycine & - & + & + \\
\hline L-Proline & - & + & - \\
\hline L-Serine & + & - & - \\
\hline Inosine & - & + & + \\
\hline Glycerol & - & + & + \\
\hline \multicolumn{4}{|l|}{ Fatty acid content (\%) } \\
\hline $16: 1 \omega 7 c$ and/or $15: 0$ iso $2-\mathrm{OH}$ & 38.8 & 38.6 & ND \\
\hline
\end{tabular}

and at $\mathrm{pH} 4.1-8.8$; however, they did not grow at below $\mathrm{pH} 3.1$ or above $\mathrm{pH}$ 9.3. They grew in the presence of $1-12 \% \mathrm{NaCl}$, but no growth was observed when $\mathrm{NaCl}$ was absent or present at $15 \%$. They grew under anaerobic conditions, showed catalase, oxidase and urease activities and reduced nitrate to nitrite. They grew on the following carbon sources: glucose, arabinose, mannose, mannitol, $\mathrm{N}$ acetylglucosamine, maltose, gluconate, malate and citrate. They did not hydrolyse gelatin, urea or aesculin and did not show arginine dihydrolase activity or produce indole. Under anaerobic conditions, they produced acid, but no gas, from D-glucose. They were also susceptible to the vibriostatic agent $\mathrm{O} / 129$. The predominant fatty acids of strain MANO22D ${ }^{\mathrm{T}}$ were $16: 1 \omega 7 c$ and/or $15: 0$ iso $2-\mathrm{OH}$, $18: 1 \omega 7 c, 16: 0$ and $14: 03-\mathrm{OH}$ and/or $16: 1$ iso I.

The 16S rRNA gene sequence of MANO22 ${ }^{\mathrm{T}}$ was 93.3-98.65\% similar to those of Vibrio and Photobacterium strains, its closest phylogenetic neighbour being V. rumoiensis $\mathrm{S}-1^{\mathrm{T}} \quad\left(=\right.$ FERM P-14531 $\left.{ }^{\mathrm{T}}\right) \quad(98.65 \%)$. A phylogenetic tree constructed by using the neighbourjoining method clearly showed that $\mathrm{MANO} 22 \mathrm{D}^{\mathrm{T}}$ and MANO22P both belong to the genus Vibrio, albeit constituting a separate branch with respect to the main
Vibrio group (Fig. 1). DNA-DNA relatedness studies were performed to determine the genomic relationship between MANO22P, MANO22D ${ }^{\mathrm{T}}$ and $V$. rumoiensis FERM P$14531^{\mathrm{T}}$. The value for DNA-DNA relatedness between MANO22P and MANO22 ${ }^{\mathrm{T}}$ was $96 \%$, but the relatedness values between the novel isolates and $V$. rumoiensis FERM P$14531^{\mathrm{T}}$ were $7.4 \%\left(\right.$ MANO22 $\left.^{\mathrm{T}}\right)$ and $3.9 \%(\mathrm{MANO} 22 \mathrm{P})$. Taken together, these observations indicate that strains MANO22D ${ }^{\mathrm{T}}$ and MANO22P represent a novel species of the genus Vibrio, for which the name Vibrio litoralis sp. nov. is proposed.

\section{Description of Vibrio litoralis sp. nov.}

Vibrio litoralis (li.to.ra'lis. L. masc. adj. litoralis of the shore, a shallow-water dweller).

Cells are Gram-negative, slightly curved rods that are $0.6-0.8 \mu \mathrm{m}$ wide and $2.0-3.0 \mu \mathrm{m}$ long. Motile due to the presence of at least one polar flagellum per cell. Colonies on MA are pale yellow, smooth, round or slightly irregular in shape and measure $1.5-2.0 \mathrm{~mm}$ in diameter after 3 days culture on MA plates. Bioluminescence is not observed. Growth occurs when $1-12 \% \mathrm{NaCl}$ is present, but not when $\mathrm{NaCl}$ is absent or at concentrations of $15 \%$. Growth occurs at $4-45^{\circ} \mathrm{C}$ and at $\mathrm{pH} 4.1-8.8$. Optimal conditions are $25-30^{\circ} \mathrm{C}, \mathrm{pH} 6.9$ and $3 \% \mathrm{NaCl}$. Susceptible to the vibriostatic agent $\mathrm{O} / 129$ and is oxidase- and catalasepositive. Reduces nitrate to nitrite, but not further to $\mathrm{N}_{2}$. Facultatively anaerobic; acid, but no gas, is produced from glucose. The following substrates can be utilized as sole carbon and energy sources: glucose, arabinose, mannose, mannitol, $\mathrm{N}$-acetylglucosamine, maltose, gluconate, malate and citrate. Gelatin, urea and aesculin are not hydrolysed. API ZYM tests show activities for alkaline phosphatase, esterase (C4), esterase lipase (C8), leucine arylamidase, valine arylamidase, acid phosphatase, naphthol-AS-BIphosphohydrolase and $N$-acetyl- $\beta$-glucosaminidase. Arginine dihydrolase, lipase (C14), cystine arylamidase, trypsin, $\alpha$-chymotrypsin, $\alpha$-galactosidase, $\beta$-galactosidase, $\beta$-glucuronidase, $\beta$-glucosidase, $\alpha$-glucosidase, $\beta$-glucosidase, $\alpha$ mannosidase and $\alpha$-fucosidase activities are not observed. The predominant fatty acids are $16: 1 \omega 7 c$ and/or $15: 0$ iso 2 $\mathrm{OH}(38.62 \%), 18: 1 \omega 7 c(19.45 \%), 16: 0$ (13.49\%), $14: 03-$ $\mathrm{OH}$ and/or $16: 1$ iso I $(7.11 \%), 12: 0(3.65 \%)$ and $18: 0$ iso $(3.44 \%)$.

The type strain, MANO22 $\mathrm{D}^{\mathrm{T}}\left(=\mathrm{KCTC} 12520^{\mathrm{T}}=\mathrm{DSM}\right.$ $\left.17657^{\mathrm{T}}\right)$, and a reference strain, MANO22P (=KCTC 12519), were isolated from a tidal flat area of Dae-Chun, Chung-Nam, Korea.

\section{Acknowledgements}

The authors are supported by grant BDM0200524, NNM0100512, KRIBB Research Initiative Program and Environmental Biotechnology National Core Research Center (KOSEF: R15-2003-012-02002-0) from the Ministry of Science and Technology (MOST) of the Republic of Korea. 


\section{References}

Austin, B. (1988). Marine Microbiology. Cambridge: Cambridge University Press.

Bae, J. W., Rhee, S. K., Park, J. R., Chung, W. H., Nam, Y. D., Lee, I., Kim, H. \& Park, Y. H. (2005). Development and evaluation of genome-probing microarrays for monitoring lactic acid bacteria. Appl Environ Microbiol 71, 8825-8835.

Baumann, P. \& Baumann, L. (1984). Genus II. Photobacterium Beijerinck 1889, $401^{\mathrm{AL}}$. In Bergey's Manual of Systematic Bacteriology, vol. 1, pp. 539-545. Edited by N. R. Krieg \& J. G. Holt. Baltimore: Williams \& Wilkins.

Baumann, P. \& Schubert, R. H. W. (1984). Family II. Vibrionaceae Veron 1965, 5245 ${ }^{\mathrm{AL}}$. In Bergey's Manual of Systematic Bacteriology, vol. 1, pp. 516-517. Edited by N. R. Krieg \& J. G. Holt. Baltimore: Williams \& Wilkins.

Gomez-Gil, B., Tron-Mayén, L., Roque, A., Turnbull, J. F., Inglis, V. \& Guerra-Flores, A. L. (1998). Species of Vibrio isolated from hepatopancreas, haemolymph and digestive tract of a population of healthy juvenile Penaeus vannamei. Aquaculture 163, 1-9.

Gomez-Gil, B., Roque, A. \& Turnbull, J. F. (2000). The use and selection of probiotic bacteria for use in the culture of larval aquatic organisms. Aquaculture 191, 259-270.

Gomez-Gil, B., Roque, A. \& Velasco-Blanco, G. (2002). Culture of Vibrio alginolyticus $\mathrm{C} 7 \mathrm{~b}$, a potential probiotic bacterium, with the microalga Chaetoceros muelleri. Aquaculture 211, 43-48.

Gonzalez, J. M., Mayer, F., Moran, M. A., Hodson, R. E. \& Whitman, W. B. (1997). Microbulbifer hydrolyticus gen. nov., sp. nov., and Marinobacterium georgiense gen. nov., sp. nov., two marine bacteria from a lignin-rich pulp mill waste enrichment community. Int J Syst Bacteriol 47, 369-376.

Gordon, R. E., Haynes, W. C. \& Pang, C. H.-N. (1973). The Genus Bacillus. Washington DC: United States Department of Agriculture.

Hjeltnes, B. \& Roberts, R. J. (1993). Vibriosis. In Bacterial Diseases of Fish, pp. 109-121. Edited by V. Inglis, R. J. Roberts \& N. R. Bromage. Oxford: Blackwell Scientific.

Kim, B. S., Oh, H. M., Kang, H., Park, S. S. \& Chun, J. (2004). Remarkable bacterial diversity in the tidal flat sediment as revealed by $16 \mathrm{~S}$ rDNA analysis. J Microbiol Biotechnol 14, 205-211.
Kim, B. S., Oh, H. M., Kang, H. \& Chun, J. (2005). Archaeal diversity in tidal flat sediment as revealed by $16 \mathrm{~S}$ rDNA analysis. J Microbiol 43, 144-151.

Kimura, M. (1980). A simple method for estimating evolutionary rates of base substitutions through comparative studies of nucleotide sequences. J Mol Evol 16, 111-120.

Lightner, D. V. (1993). Diseases of cultured penaeid shrimp. In $C R C$ Handbook of Mariculture, 2nd edn, vol. 1, pp. 393-486. Edited by J. P. McVey. Boca Raton: FL: CRC Press.

Mellado, E., Moore, E. R. B., Nieto, J. J. \& Ventosa, A. (1996). Analysis of $16 \mathrm{~S}$ rRNA gene sequences of Vibrio costicola strains: description of Salinivibrio costicola gen. nov., comb. nov. Int J Syst Bacteriol 46, 817-821.

Saitou, N. \& Nei, M. (1987). The neighbor-joining method: a new method for reconstructing phylogenetic trees. Mol Biol Evol 4, 406-425.

Sambrook, J., Fritsch, E. F. \& Maniatis, T. (1989). Molecular Cloning: a Laboratory Manual, 2nd edn. Cold Spring Harbor, NY: Cold Spring Harbor Laboratory.

Sasser, M. (1990). Identification of bacteria by gas chromatography of cellular fatty acids. Technical Note 101. Newark, DE: MIDI Inc.

Thompson, J. D., Gibson, T. J., Plewniak, F., Jeanmougin, F. \& Higgins, D. G. (1997). The CLUSTAL_X windows interface: flexible strategies for multiple sequence alignment aided by quality analysis tools. Nucleic Acids Res 25, 4876-4882.

Thompson, F. L., Hoste, B., Vandemeulebroecke, K. \& Swings, J. (2003). Reclassification of Vibrio hollisae as Grimontia hollisae gen. nov., comb. nov. Int J Syst Evol Microbiol 53, 1615-1617.

Thompson, F. L., lida, T. \& Swings, J. (2004). Biodiversity of vibrios. Microbiol Mol Biol Rev 68, 403-431.

Yoon, J. H., Lee, S. T. \& Park, Y. H. (1998). Inter- and intraspecific phylogenetic analysis of the genus Nocardioides and related taxa based on 16S rDNA sequences. Int J Syst Bacteriol 48, 187-194.

Yoon, J. H., Kang, K. H. \& Park, Y. H. (2003). Halobacillus salinus sp. nov., isolated from a salt lake on the coast of the East Sea in Korea. Int J Syst Evol Microbiol 53, 687-693.

Yumoto, I. I., Iwata, H., Sawabe, T., Ueno, K., Ichise, N., Matsuyama, H., Okuyama, H. \& Kawasaki, K. (1999). Characterization of a facultatively psychrophilic bacterium, Vibrio rumoiensis sp. nov., that exhibits high catalase activity. Appl Environ Microbiol 65, 67-72. 